\title{
Relationship of the Brussels I Regulation vis-à-vis Legal Remedies Provided by National Enforcement Laws
}

\author{
DAMJAN OROŽ
}

\begin{abstract}
Article discuss the impact of the Brussels I and Brussels I bis Regulations on Slovenian enforcement proceedings. The aim of the Brussels I bis Regulation is to ensure creditors a simpler but mostly quicker access to enforcement in case a judgment must be enforced in a state other than the Member State of origin. The new regulatory framework will certainly facilitate quicker access to enforcement for creditors. However, this can only be ensured categorically in the first phase of enforcement, i.e. the seizure of assets (distraint). In subsequent enforcement phases successful enforcement in favour of the creditor could be stayed if the debtor decides to enforce grounds used to challenge the enforceability of a foreign judgment. A major distinction is that the control of enforceability will only proceed if and when the debtor so requests.
\end{abstract}

Keywords: - enforcement in the Member State of enforcement • foreign judgment $\bullet$ application for refusal of enforceability $\bullet$ objection against the enforcement order $\bullet$ creditor $\bullet$

CORRESPONDENCE ADDRESS: Damjan Orož, MSc, senior judge of the Ljubljana Higher Court, Tavčarjeva 9, 1000 Ljubljana, Slovenia, e-mail: damjan.oroz@gmail.com. 
\begin{tabular}{l|l}
150 & $\begin{array}{l}\text { LEXONOMICA } \\
\text { D. Orož: Relationship of the Brussels I Regulation vis-à-vis Legal Remedies Provided by } \\
\text { National Enforcement Laws }\end{array}$
\end{tabular}

\section{Introduction}

Regulation (EU) No 1215/2012 of the European Parliament and of the Council of 12 December 2012 on jurisdiction and the recognition and enforcement of judgments in civil and commercial matters ${ }^{1}$ (recast; hereinafter: the Brussels I bis Regulation) inserts certain new rules relating to cross-border enforcement into enforcement proceedings. The Brussels I bis Regulation is a »third generation regulation« (Ekart, 2018: 256), which poses numerous new questions, even in relation to the legal frameworks of individual states. One of those core questions in enforcement proceedings, is how and in what proceedings will defences be enforced under the new regulatory framework, which will enable a debtor to challenge the enforceability of a foreign judgment (in terms of Article 2 of the Brussels I bis Regulation; also hereinafter: foreign judgment). I will highlight some dilemmas and practical solutions adopted by Austrian and German enforcement laws. In order to emphasize the new features introduced into cross-border enforcement by the Brussels I bis Regulation, I will also point out the differences in comparison with Council Regulation (EC) No 44/2001 on jurisdiction and the recognition and enforcement of judgments in civil and commercial matters ${ }^{2}$ (hereinafter: the Brussels I Regulation). The Brussels I Regulation is still used in cross-border enforcement, given that the Brussels I bis Regulation only applies to the enforcement of the judgments that were issued in court proceedings initiated after 10 January 2015 (Article 66(2) of the Brussels I bis Regulation).

\section{Cross-border enforcement in general}

Enforcement titles in judicial enforcement can also be enforceable decisions or documents, for which a ratified and published international treaty or legal act of the European Union, directly applicable in the Republic of Slovenia, stipulates that they comprise an enforcement title (third point of Article 17 of the Claim Enforcement and Security Act; ${ }^{3}$ hereinafter: the ZIZ). In that case this involves international or cross-border enforcement (Ekart and Rijavec, 2010: 26). Its characteristic is that a distinction be made between the Member State of origin and the Member State of enforcement. The Member State of origin provides the enforcement title, while a creditor in the Member State of enforcement requests enforcement on the debtor «s assets (attachment of assets) on the basis of that enforcement title.

\footnotetext{
${ }^{1}$ OJ L 351, 20. 12. 2012, p. 1-32.

${ }^{2}$ OJ L 012, 16. 1. 2001, p. 1-23.

${ }^{3}$ OJ of the Republic of Slovenia, Nos. 3/07 [official consolidated text], 93/07, 37/08 - ZST-1, 45/08 ZArbit, 28/09, 51/10, 26/11, 17/13 - Constitutional Court Decision, 45/14 - Constitutional Court Decision, 53/14, 58/14 - Constitutional Court Decision, 54/15, 76/15 - Constitutional Court Decision and 11/18.
} 
For cross-border enforcement to be permitted, it is essential under the Brussels I Regulation that the creditor has a certificate of a judgment «s enforceability issued in the Member State of origin. The second requirement is that the enforcement title is declared enforceable in a special procedure (exequatur procedure or recognition procedure) in the Member State of enforcement (Rijavec, 2006: 1 and 4; Ekart, 2010: 27). The power of a domestic enforcement title is therefore conferred upon the foreign enforcement title in the Member State of enforcement.

In legal theory two functions are attributed to the exequatur procedure (Wolf, 2016: 4). The first function is that a foreign judgment must be transposed into the domestic legal system and be declared enforceable. Secondly, the exequatur procedure also has an »inspection function", which is reflected in protection or in the scope of protection of the debtor in the Member State of enforcement. The European Court of Human Rights (hereinafter: the ECtHR) addresses the question of the recognition of foreign final judgments either as an essentialia of a certain right (e. g. Article 8 of the European Convention on Human Rights and Fundamental Freedoms; hereinafter: ECHR; the ECtHR in the case of Wagner v. Luxembourg $)^{4}$ or as an accesoria of the right to a fair trial (Article 6 of the ECHR; the ECtHR in the case of McDonald v. France). ${ }^{5}$

It is essential for the exequatur procedure under the Brussels I Regulation that a judgment that is issued and enforceable in a Member State is enforced in Slovenia only if such a judgment is declared enforceable in the Member State of enforcement at the request of any interested party. District courts decide on the declaration of enforceability in Slovenia (Article 39(1) of the Brussels I Regulation). A judgment is declared enforceable immediately upon fulfilling the formalities under Article 53 of the Brussels I Regulation. The applicant must present both a copy of the judgment that fulfils the conditions required for the approval of its authenticity and a certificate of enforceability of the Member State of origin. ${ }^{6}$ Unlike under the Private International Law and Procedure $\mathrm{Act}^{7}$ - hereinafter ZMZPP, under the Brussels I Regulation the effect of the judgment «s enforceability is only constituted with the issuance of the exequatur order, thereby preventing a decision to be adopted on the declaration of enforceability as an incidental question ${ }^{8}$ (Ekart and Rijavec, 2010: 47). During that phase the district court cannot conduct the examination under Articles 34 and 35 of the Brussels I Regulation. Rather, the latter can only be examined on a defence (objection), while the appellate (supreme) court can conduct the test on an appeal (Articles 43(2) and 44 of the Brussels I Regulation). The court with which a legal remedy is lodged can refuse or revoke a declaration of enforceability under the grounds referred to in Articles 34 and 35 of the Brussels I Regulation. During the declaration of enforceability procedure, defences are

\footnotetext{
${ }^{4}$ Case No. 76240/01 from 28. June 2007.

${ }^{5}$ Case No. 18648/04 from 29 April 2008. See Sladič, 2016.

${ }^{6}$ Instances when a certificate is not required are set out in Article 55 of the Brussels I Regulation.

${ }^{7}$ OJ of the Republic of Slovenia, Nr. 56/1999.

${ }^{8}$ OJ of the Republic of Slovenia, Nos. 56/99 and 45/08 - ZArbit.
} 
$152 \mid \begin{aligned} & \text { LEXONOMICA } \\ & \text { D. Orož: Relationship of the Brussels I Regulation vis-à-vis Legal Remedies Provided by } \\ & \text { National Enforcement Laws }\end{aligned}$

resolved under (the so-called contrôle limité system; Ekart and Rijavec, 2010: 47):

- Article 34 of the Brussels I Regulation, which comprises defences that indicate that a judgment is manifestly contrary to the public policy of the Member State of enforcement; ${ }^{9}$ breaches the principle of the adversarial procedure in terms of the second paragraph of that regulation; is irreconcilable with a judgment given in a dispute between the same parties in the Member State of enforcement; or, is irreconcilable with an earlier judgment delivered in a Member State or a third country involving the same cause of action and between the same parties, provided that the earlier judgment fulfils the conditions necessary for its recognition in the Member State of enforcement.

- Article 35 of the Brussels I Regulation, which comprises defences indicating that a judgment did not take in account the rules of jurisdiction relating to insurance disputes, consumer disputes and disputes for which exclusive grounds of jurisdiction are set out.

- Article 57 of the Brussels I Regulation, if the enforcement of an authentic instrument is manifestly contrary to public policy in the Member State of enforcement.

These defences must be utilised by the debtor in the procedure for the declaration of enforceability. The non-enforceability defence does not constitute an admissible ground for defence in enforcement proceedings. As with domestic enforcement titles, under no circumstances may a judgment be reviewed as to its substance (legal correctness of the judgment), which is also set out in the Brussels I Regulation for the procedure of declaring enforceability (Article 36 of the Brussels I Regulation; prohibition of révision au fond). This means that, in the exequatur procedure, the court of the Member State of enforcement cannot review whether the court in the Member State of origin correctly applied procedural rules or correctly and fully determined the facts and applied substantive law to these facts in the correct manner. The debtor has all the conventional defences in objection against the enforcement order under Article 55 of the ZIZ available to them in enforcement proceedings. A typical defence in enforcement proceedings in that case would be payment already made. The majority opinion in legal theory is that the exequatur procedure is not used to address the defences that do not infringe on the prohibition of reviewing the substance (content) of a judgment, as they are used to enforce the grounds that the court could not have taken into account at the time the judgment was delivered. Under Slovene law, these defences can be enforced in a subsequent action to oppose enforcemen by way of an objection against an enforcement order (Zöller, 2014: 3164; Ekart and Rijavec, 2010: 130-131).

\footnotetext{
${ }^{9}$ Decision of the Supreme Court Cpg 4/2006, ECLI:SI:VSRS:Cpg.4.2006. A situation that is contrary to public policy only occurs if the result of the recognition is simply intolerable. The mere simple contradiction of national regulations does not suffice for a court decision of an EU Member State to be contrary to the public policy of the Member State where the recognition procedure is carried out. The counterparty claimed that the witness they proposed was not re-examined. That does not constitute conduct that is manifestly contrary to the public policy of the Republic of Slovenia.
} 
Pursuant to Article 39 of the Brussels I bis Regulation, a judgment that is issued and enforceable in a Member State is also enforceable in other Member States, without the necessity of taking further steps to declare it enforceable. That means that the Brussels I bis Regulation (unlike the Brussels I Regulation) relinquished the need for a special exequatur procedure (Wolf, 2016: 5). In order to enforce a foreign judgment in the Member State of enforcement it is therefore sufficient that the creditor only submits to the court a copy of the judgment that satisfies the conditions required to establish its authenticity, along with a certificate issued in accordance with Article 53 of the Brussels I bis Regulation. That certificate confirms the enforceability of a judgment in the Member State of origin; contains an extract from the judgment; and, where required, also contains material information regarding recoverable costs of proceedings and calculation of interest (Article 42(1) of the Brussels I bis Regulation).

However, the exequatur«s inspection function has not been completely omitted from the Brussels I bis Regulation. Rather, it has been moved to the subsequent phases of enforcement. Unlike in the Brussels I Regulation, the inspection function is performed on the initiative of the party and not every time, as is the case in the system that sets out a special exequatur procedure (Nunner - Krautagasser, 2016: 68). Pursuant to Article 45 of the Brussels I bis Regulation the recognition of a judgment on the application of any interested party may be refused if the conditions therefore are satisfied.

The Brussels I bis Regulation in Subsection 2 determines how the procedure of enforcement refusal is carried out. Article 46 provides that the enforcement of a judgment is refused at the request of the person against whom enforcement is requested, if one of the grounds from Article 45 of the Brussels I bis Regulation is present. Only the debtor is entitled to lodge an application for the refusal of enforceability. This stands in contradistinction to the Brussels I Regulation, where the burden of granting enforceability was on the creditor, and where in order to verify the compliance or existence of conditions for the recognition of a foreign judgment in a Member State the exequatur procedure was always carried out, the applicant was always the creditor (Ekart and Rijavec, 2010: 68). On the other hand, this type of control under the Brussels I bis Regulation is not always carried out during enforcement in the Member State of enforcement. Instead, it is only carried out on a proposal or application for the refusal of enforcement. Only the debtor or the debtor«s legal successor may lodge such application, never the creditor (Rauscher, Lieble, Mankowski, Pabst, Staudinger, 2016: 1081). This procedure can also be referred to as an inverse exequatur procedure (Sladič, 2016).

If the debtor had the possibility to contest recognition in the procedure for the recognition of enforceability under the Brussels I Regulation, thereby having autonomous (EU) legal remedies at the debtor «s disposal in that regard, the debtor «s defence strategy changed with the Brussels I bis Regulation. On the one hand, the creditor «s position has improved under the Brussels I bis Regulation as the creditor 
$154 \mid \begin{aligned} & \text { LEXONOMICA } \\ & \text { D. Orož: Relationship of the Brussels I Regulation vis-à-vis Legal Remedies Provided by } \\ & \text { National Enforcement Laws }\end{aligned}$

is no longer required to initiate exequatur procedures (cutting the creditor «s costs in general; Wolf, 2016: 5). On the other hand, the new Brussels I bis Regulation relies on fragmented legal remedies in the national regulatory framework, which could result in a heavy burden for creditors. It is therefore still unclear whether the changes set forth in the Brussels I bis Regulation will bring about the desired improvement in the free movement of judgments (Schlosser and Hess, 2015: 230). Even the burden of producing evidence and meeting the burden of proof has shifted from the creditor to the debtor (Schlosser and Hess, 2015: 245) under Article 45 of the Brussels I bis Regulation. Nothing can get done without the debtor«s proposal. The application to refuse enforcement has a curative ex post effect, with the debtor being required to enforce that effect in proceedings on refusal of enforcement.

A further significant difference with the Brussels I Regulation is that the competent authority is not mindful of the existence of autonomous (EU) obstacles for enforcement, nor is there any requirement to prove such existence ex officio. This applies to all obstacles under Article 45 of the Brussels I bis Regulation and is a logical consequence of the fact that the enforceability of a foreign judgment can only be reversed on a proposal/application.

The third logical consequence of proceedings initiated on a party «s proposal is that the application for the refusal of enforcement has the nature of a »negative application«, i.e. there are no grounds for enforcement. The mere lodging of that application does not cause the enforcement to be stayed, i.e. the application does not have an immediate suspensive effect, which is also indicated in Article 44 of the Brussels I bis Regulation (Rauscher, Lieble, Mankowski, Pabst, Staudinger, 2016: 1117). Articles 47 through 51 of the Brussels I bis Regulation set out the minimum guidelines for the procedure in which a decision is made on the debtor «s application for refusal of enforcement while other matters are surrendered to the national laws of each Member State.

\section{Brussels I bis Regulation and the ZIZ}

The Slovenian legislator implemented the regulatory framework under the Brussels I bis Regulation in the ZIZ with the adoption of the Act Amending the Claim Enforcement and Security Act (ZIZ-L). ${ }^{10}$ The German legislator accomplished this by structurally basing the procedure regarding the application for enforcement refusal on an action to oppose enforcement (Schlosser and Hess, 2015: 245), while also omitting the concept of granting an enforcement clause or issuing an enforceable copy of the enforcement title (Article 1112 of the ZPO) ${ }^{11}$ for these enforcement titles (Wolf, 2016: 6). Like the action to oppose enforcement, the claim under Article 1115 of the ZPO is drafted as procedural and constitutive by nature (Rauscher, Lieble, Mankowski, Pabst, Staudinger, 2016: 1084).

\footnotetext{
${ }^{10}$ OJ of the Republic of Slovenia, No. 11/18.

${ }^{11}$ Zivilprocessordnung (Civil Procedure Code) as amended on 5 December 2005 (Federal Law Gazette I p. 3202; 2006 I p. 431; 2007 I p. 1781), last amended by Article 2 of the Law of 12 July 2018 (BGB1 $1151)$.
} 
During Slovenian enforcement proceedings, the debtor can defend against the enforcement of a foreign judgment by lodging an application for the refusal of enforcement on the basis of Article 46 of the Brussels I bis Regulation. That application is not a defence against an enforcement order and is enforced in nonlitigious proceedings before the district court. Slovenia notified the European Commission that the court having jurisdiction to hear applications under Article 75(a) of the Brussels I bis Regulation is the district court (Article 47(1) of the Brussels I bis Regulation). With a decision upholding the action brought, the court renders the enforcement inadmissible in Slovenia on the basis of a specifically determined enforcement title. The effect of such an order only extend to Slovenia. If the creditor initiates enforcement proceedings against a debtor, even in Germany, for example, the debtor must apply for the refusal of enforcement before a German court (specified in Article 1115 of the ZPO; Rauscher, Lieble, Mankowski, Pabst, Staudinger, 2016: 1120). That is understandable, since, for example, ordre public (Article 45(1)(a) of the Brussels I bis Regulation) can differ among Member States in, therefore resulting in a different decision in the Member States of enforcement. During the two procedures of the refusal of enforceability in both Member States there is no relation of lis pendens or recognition (Zöller, 2014: 3161). There is a slight difference regarding the obstacle referred to in Article 45(1)(b) (breach of the right to participate in proceedings) and Article 45(1)(e) of the Brussels I bis Regulation (generally speaking a breach of the jurisdiction for decision-making under Sections 3, 4, ${ }^{12}$ and 5 and 6 under Chapter II of the Brussels I bis Regulation), which require a uniform EU-autonomous interpretation. In terms of these grounds, the declaratory effect should also extend to other Member States of enforcement (Rauscher, Lieble, Mankowski, Pabst, Staudinger, 2016: 1122).

The basic legal remedy available to the debtor who defends on the grounds of enforcement refusal is therefore an application for the refusal of enforcement. Outside of that, if the debtor challenges the enforceability of a foreign judgment, the creditor can lodge a "positive application« for a decision that no grounds exist for the refusal of recognition under Article 45 of the Brussels I bis Regulation (Article 36(2) of the Brussels I bis Regulation). The application for a positive finding that there were no grounds to refuse recognition can be lodged by any party, even by the debtor (the latter particularly before the expected enforcement; Schlosser and Hess, 2015: 209; Rauscher, Lieble, Mankowski, Pabst, Staudinger, 2016: 946). That question can be resolved also in a (preliminary) incidental manner, if the outcome of proceedings before a court of a Member State depends on the determination of an incidental question of refusal of recognition (Article 36(3) of the Brussels I bis Regulation). The question of the relation between both procedures is certainly immediately posed (Wolf, 2016: 7 and 8), but that question is of minor significance in the enforcement proceedings.

\footnotetext{
${ }^{12}$ A request for a preliminary ruling has been lodged in that regard regarding the question of whether the court of origin verifies ex officio whether there has been a breach of the rules of jurisdiction set out in Chapter II, Section 4 of the Brussels I bis Regulation, and it may inform the consumer of any breach that is established during the issue of the certificate under Article 53 of the Brussels I bis Regulation, and enable the consumer to consider the possibility of availing himself of the remedy provided for in Article 45 of the Brussels I bis Regulation (Case C-347/18, Avv. Alessandro Salvoni v Anna Maria Fiermonte, OJ C 285, 13. 8. 2018, p. 26-26).
} 
$156 \mid \begin{aligned} & \text { LEXONOMICA } \\ & \text { D. Orož: Relationship of the Brussels I Regulation vis-à-vis Legal Remedies Provided by } \\ & \text { National Enforcement Laws }\end{aligned}$

It is more interesting to see how the lodged application for the refusal of enforcement impacts the enforcement proceedings and whether the debtor also has any legal remedy available in the enforcement proceedings.

If an application for the refusal of enforcement has been lodged, the debtor can propose numerous remedies such as: the limitation of enforcement proceedings to protective measures; making enforcement conditional on the provision of such security as the court shall determine (the creditor is required to pay the security); or, propose that the court suspend, wholly or in part, the enforcement proceedings. If the enforceability of a judgment is temporarily suspended in the Member State of origin, the debtor may propose the temporary suspension of the enforcement. ${ }^{13}$ The protective measures and the temporary suspension of proceedings are addressed under Slovenian law in limited ways. The court may order the seizing of the debtor «s assets and, the debtor may propose the postponement of the enforcement (Ekart and Rijavec, 2010: 268).

The question is posed whether the debtor can enforce the lack of enforceability with the objection against the enforcement order (Articles 53 and 55 of the ZIZ) in lieu of the application for the refusal of enforceability. If the answer is affirmative, then the scope of the admissible defence needs to be assessed with a measuring tool (yardstick; Wolf, 2016: 6) under Article 45 of the Brussels I bis Regulation and with the prohibition of the révision au fond under Article 52 of the Brussels I bis Regulation. According to the provisions of both Article 46 and Article 47(3) of the Brussels bis Regulation we can conclude that the answer is negative. The Brussels I bis Regulation governs the lodging of the application for the refusal of enforcement. In Slovenia a court authorised to rule on that application conveyed is the district court (Article a42.b of the ZIZ), despite local courts are being authorised for enforcement and the resolution of objection against an enforcement order (Article 5 of the ZIZ). However, the Brussels I bis Regulation in subsection 2 of section 3 sets out the »minimum procedural requirements. « The remaining procedural framework is left to the domain of national laws. Given that both the legal and political objective of the new regulatory framework was to transfer procedure for refusal of enforcement into legal remedies of enforcement law (the German legislator accomplished this by relying on the Vollstreckungsgegensklage under Article 767 of the ZPO (Rauscher, Lieble, Mankowski, Pabst, Staudinger, 2016: 1124), while Austrian legal theory indicates positions that given the currently applicable EO this would be most easily addressed either with a suspension proposal under Article 39 of the EO or in an impugnament action (Nunner - Krautagasser, 2016: 8 and 9)). So, it is also possible to make an assumption that same applies to Slovenian «s legal system - that the Brussels I bis Regulation does not prohibit the adoption of a ruling on this question in enforcement proceedings on the basis of the defendant «s defence, particularly according to introductory provision (recital) no. 30 of the Brussels I bis Regulation. But, in that case court decision effects only in that particular enforcement procedure. The issue that the non-existence of obstacles under Article

\footnotetext{
${ }^{13}$ Compare Article 44 of the Brussels I bis Regulation with Article 1116 of the ZPO.
} 
45 of the Brussels I bis Regulation can be decided on as an incidental question is already provided for in the third paragraph of Article 36 of the Brussels I bis Regulation. Enforcement of this particular defence would not be considered an incidental question but rather an independent ground for a defence. In addition, such legal rule could also be justified on the principle of the equality and effectiveness of EU law. ${ }^{14}$ Under the Slovenian legal system it is important to consider Article 94 of the ZMZPP, which sets out the conditions for the enforcement of a foreign judgment, i.e. a judgment delivered by a third-country authority. The sixth paragraph of Article 108 of the ZMZPP stipulates that if no separate order was issued on the recognition of a foreign judgment or arbitration award any court can decide on the recognition of such decision as an incidental question with effect only for that proceeding. If the enforcement court rules on the recognition of such judgment as an incidental question, ${ }^{15}$ then the contrary also applies on that ground - the defendant «s defence maintaining that the decision of the enforcement court recognising the judgment as an incidental question is erroneous. ${ }^{16}$ In light of the framework under the Brussels I bis Regulation, the prohibition of the enforcement of the grounds under Article 45 of the Brussels I bis Regulation through an objection against the enforcement order in the enforcement proceedings would mean that the debtor under a foreign enforcement title is in a better position than the debtor under the enforcement title for which the Brussels I bis Regulation applies. Such an interpretation, in this author«s opinion, would be in violation of the principle of equal treatment.

The appropriateness of a regulatory framework that reviews conditions for the refusal of enforceability through multiple legal remedies (the application of the creditor/debtor claiming that no obstacles under Article 45 exist, intermediary declaratory claim when a ruling is adopted as an incidental question, negative intermediary declaratory claim or defence in enforcement proceedings), and/or numerous legal options that cause unnecessary confusion, at least regarding the relationship between these legal options (Wolf, 2016: 7), is an entirely different matter. An answer needs to be found to the questions that will be posed regarding not only the relationship between an objection against an enforcement order on the grounds of enforcement refusal and the debtor«s application for the refusal of enforcement, but also the creditor«s (expected) application to determine the lack of grounds for refusal under Article 45 of the Brussels I bis Regulation. Given that an objection against the enforcement order is a typical legal remedy provided in enforcement proceedings, which as such has an effect solely inside enforcement proceedings, it is submitted that if an application is lodged (by either the creditor or debtor) the enforcement court can suspend (stay) the decision-making procedure regarding the defence. Ultimately, the decision-making process regarding the refusal of enforcement has an erga omnes effect, which is not the case during the decisionmaking regarding an objection against the enforcement order. In the broader sense,

\footnotetext{
${ }^{14}$ Compare with case C-443/03, Götz Leffler v Berlin Chemie AG, ECLI:EU:C:2005:665; summarised under Sladič (2016).

${ }^{15}$ Decision of the Supreme Court III Ips 64/2001, ECLI:SI:VSRS:2001:III.IPS.64.2001.

${ }^{16}$ Decision VSL I Ip 2238/2012, ECLI:SI:VSLJ:2012:I.IP.2238.2012, and decision VSM Cp 2673/2002, ECLI:SI:VSMB:2003:CP.2673.2002.
} 
$158 \mid \begin{aligned} & \text { LEXONOMICA } \\ & \text { D. Orož: Relationship of the Brussels I Regulation vis-à-vis Legal Remedies Provided by } \\ & \text { National Enforcement Laws }\end{aligned}$

this is certainly an incidental question (see Article 36(3) of the Brussels I bis Regulation and, for example, Article 206 of the ZPP). This is expressly permitted, at least in the debtor «s application, under Article 44 of the Brussels I bis Regulation (on the debtor«s proposal; compare with Article 44(1)(c)).

A major deficiency of the position that the question of the existence of conditions for the refusal of enforceability should be decided on by the court in enforcement proceedings, is the limited impact of the court«s decision-making, since the decision on the objection against the enforcement order has no impact outside the proceedings in which it was adopted. On the other hand, the Brussels I bis Regulation is premised on the notion that decisions regarding the refusal of enforceability are binding, meaning that they have an effect on the loss of an enforcement title«s enforceability in the territory of the entire Member State in which such application was lodged (Nunner - Krautagasser, 2016: 9). ${ }^{17}$

\section{Conclusion}

It seems that above mentioned dilemma Slovenian legislator resolved with the ZIZ-L amending act, despite differing positions appearing in theory (Ekart and Rijavec, $2010 ; 265)$. In Article a42b of the ZIZ the legislator defined the exequatur procedure for recognition and enforcement under third-generation regulations. The legislator also set forth a new ground for the suspension of enforcement. ${ }^{18}$ The debtor will therefore be able to challenge the enforceability of a foreign judgment only with an application for the non-enforcement of a foreign judgment, while being able to propose the suspension of enforcement in enforcement proceedings. The legislator explained that the introductory provision no. 30 of the Brussels bis I Regulation was taken into account when adopting the amending act. But despite of acknowledgement of introductory provision no. 30 that it would be reasonibly for the debtor to enforce the grounds for the refusal of enforcement or for the nonenforcement of a foreign judgment in the objection against an enforcement order in proceedings before the local court, legislator decided differently.

Legislator decided against possibility provided by introductory provision no. 30 , taking into account the specific nature of the Slovene regulatory framework for enforcement proceedings. The legislator considered the concept of the enforcement court deciding on the question of the refusal of enforcement of a foreign judgment in objection proceedings as being inconsistent with the other regulatory framework of the objection proceedings. The legislator was also persuaded by the fact that district

\footnotetext{
${ }^{17}$ Nunner - Krautgasser, 2016: 9, where the author also points out the problem of the limited effect, if that matter is decided within the scope of the suspension proposal under Article 39 of the EO or with the impugnment action.

${ }^{18}$ Newly introduced point 10 of Article 71 of the ZIZ: if a debtor lodged a proposal for the nonenforcement of a foreign judgment on the basis of an EU legal act with direct application in the Republic of Slovenia, the recognition and enforcement of a foreign judgment, court settlement or authentic instrument is not required as a condition for the enforcement of a foreign judgment.
} 
courts were already authorised to adopt decisions in exequatur procedures regarding the recognition and enforcement of foreign judgments. ${ }^{19}$

\section{References}

Ekart, A. and Rijavec, V. (2010), „Čezmejna izvršba v EU: osrednja tema evropskega civilnega procesnega prava« (Ljubljana: GV Založba).

Rauscher, T., Lieble, S., Mankowski, P., Pabst, S., Staudinger, A. (2016) Europäisches Zivilprozess- und Kollisinsrescht, Brüsel Ia-VO (Ottoschmidt: Köln).

Ekart, A. (2018), in Repas, M., Rijavec, V. »Mednarodno zasebno pravo Evropske unije« (Ljubljana: Uradni list Republike Slovenije).

Rijavec, V. (2006) »Izvršilni naslov (po BU I, UEIN in slovenskem pravu)«; Evropsko procesno pravo v drugem letu članstva Slovenije v EU (Ljubljana: Nebra).

Sladič, J. (2016) »Sistem ugovorov v Uredbi Bruselj Ia«, material for the Seminar for lawyers and attorneys on European procedural law: Introduction to Brussels Ia Regulation, Ljubljana, 3 June 2016.

Schlosser, P., Hess, B. (2015) EuZPR, EU-Zivilprozessrecht mit EuGVVO, EuMahnVO, EuBagVO, EuZVO, EuBVO, Kommentar; (München: C.H.Beck).

Wolf, C. (2016) »German Understanding of Abolition of Exequatur«, Corporate Entities at the Market in the European Dimension, Portorož, 20 May; https://www.pf.um.si/site/assets/files/3545/prof_dr_christian_wolf_leibniz_universi ty_of_hannover_germany.pdf.

Zöller, R. (2014) Zivilprozessordnung: mit FamFG ([Paragraphen] 1-185, 200-270, 433-484) und Gerichtsverfassungsgesetz, den Einführungsgesetzen, mit internationalem Zivilprozessrecht, EG-Verordnungen, Kostenanmerkungen : Kommentar / begründet von Richard Zöller; bearbeitet von Reinhold Geimer ... [et al.]. (Köln: O. Schmidt).

Nunner-Krautgasser, B. (2016) »Characteristics of Austrian Remedies against Enforcement and a General Analysis of their Suitability for Achieving the Objectives of Brussels I Recast «, LeXonomica - Journal of Law and Economics, 8(2), pp. 1-12.

\footnotetext{
${ }^{19}$ Act Amending the Claim Enforcement and Security Act, EVA 2016-2030-0008 of 16 October 2017, Section 2.3 Main solutions.
} 
160 | LeXonomicA 